\title{
NOTE ON A VIRUS DISEASE OF THE CABBAGE LOOPER IN THE OTTAWA VALLEY
}

The cabbage looper, Trichoplusia ni (Hbn.), is one of a complex of Lepidoptera that attack cabbage and related crops throughout Ontario. Its population fluctuates widely from year to year, but until recently serious outbreaks of this insect rarely occurred, at least in the eastern part of the Province. However, in 1955 , a strain of the looper resistant to DDT appeared in the Ottawa Valley (2), and severe damage was reported by growers of cole crops in eastern Ontario and western Quebec. In 1957, the insect was again numerous, and in 1959 a light outbreak occurred throughout the eastern half of Ontario. At Ottawa, its numbers in 1959 were four times the recorded average for the previous 10 years*.

During experiments on chemical control of this insect, the writer examined a half-acre field of late cabbage at Aylmer, Quebec, periodically during the months of July, August, and September, 1959. On September 8, counts of surviving larvae were taken to determine the degree of control afforded by the various insecticides. On that date most of the larvae were in the final instar of the second generation, there being an average of 5.5 mature larvae per plant in the check plots. The caterpillars appeared to be normal in every respect, and most were feeding in the centre of the plants, on the heads and wrapper leaves. On September 10, the writer revisited the field and noted a dramatic change. The outer leaves of each plant contained a number of mature larvae, obviously in the early stages of disease. The caterpillars had ceased to feed, and their body colour had changed from a shiny green to a dull, pale yellow (Figure 1). Within 24 hours the infected larvae died. The body contents then turned black and the dead larvae hung limply from the plants attached only by the prolegs (Figure 2). In the final stages the skin ruptured, allowing the liquefied contents of the body to ooze out over the leaves.

The field was observed periodically until the end of September, the incidence of disease, based on the examination of 10 plants in each of the four check plots, being as follows:

\begin{tabular}{c|c|c}
\hline \hline Date & $\begin{array}{c}\text { Number of mature } \\
\text { larvae per plant }\end{array}$ & $\begin{array}{c}\text { Percentage showing } \\
\text { disease symptoms }\end{array}$ \\
\cline { 2 - 3 } September 11 & 3.7 & 60 \\
September 15 & 2.4 & 63 \\
September 18 & 1.5 & 47 \\
September 24 & 1.0 & 100 \\
\hline \hline
\end{tabular}

On September 28, the disease was noted in early-instar larvae of the third generation. Forty-two per cent of the population had already developed disease symptoms, and by mid-October not a single healthy larva of this generation could be found.

Field observations showed that the disease was widespread in populations of the looper throughout Gatineau and Hull counties of western Quebec. The writer also found it in larvae in Carleton County, Ontario, and in larvae and prepupae in York County. 


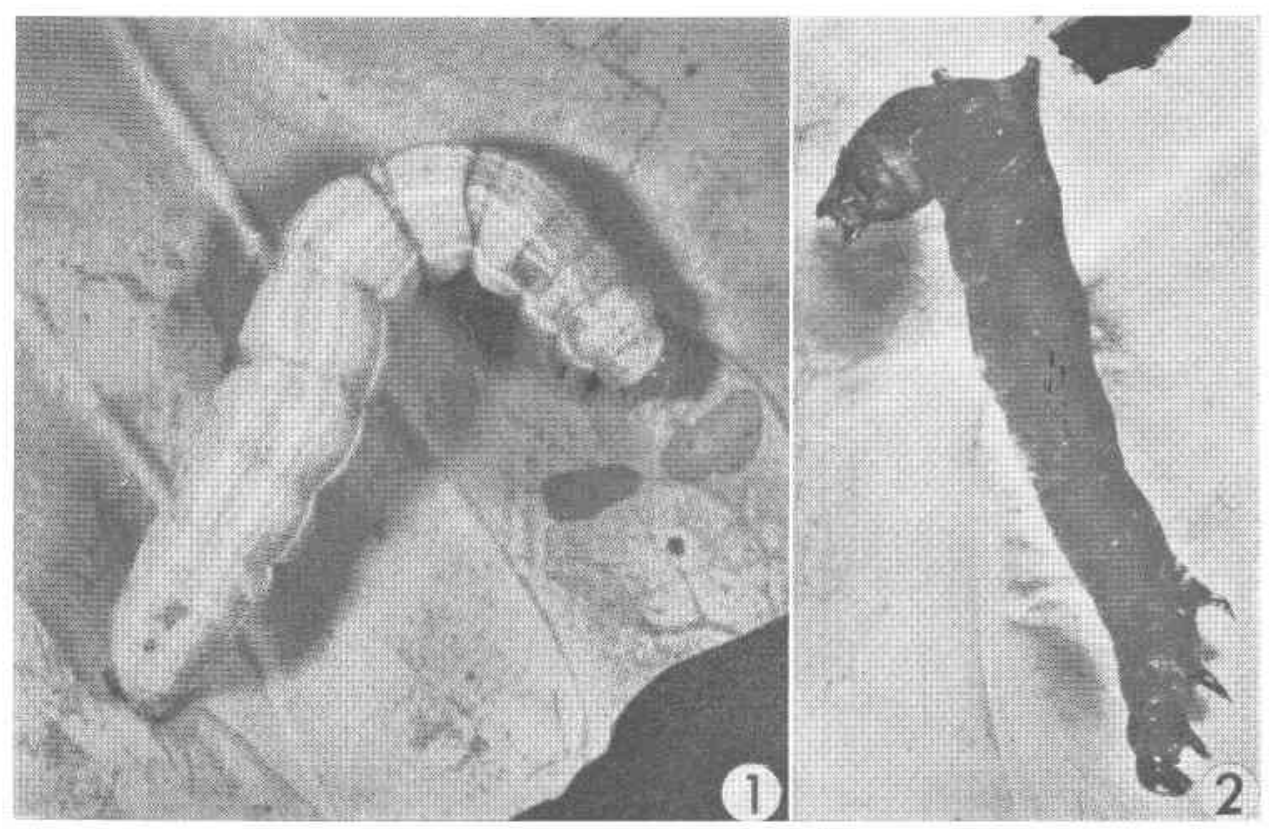

Figure 1. Mature larva in early stages of disease. Larva has ceased to feed and body colour has become pale ycllow.

Figere 2. Same larval 36 hours later. Body contents have turned black and cadaver hangs limply from the leaf attached by prolegs. 
Dead larvae contained large numbers of virus polyhedra. Examination of diseased tissues by G. E. Bucher, Entomology Research Institute for Biological Control, Belleville, Ontario, revealed that the virus had attacked the nuclei of the fat body, connective tissue, hypodermis, blood, and tracheal matrix, but not the gut, silk glands, malpighian tubules, or nerves.

This appears to be the first report of the virus from Canada, although a polyhedrosis disease of the cabbage looper, characterized by many of the above symptoms, has been known to occur in the United States for several years $(3,6)$. With the recent appearance of DDT-resistant strains of the looper and the corresponding increase in its abundance, the virus has assumed an important role in controlling natural populations of the insect $(4,5)$. Hall (1), and McEwen and Hervey (4), have artificially disseminated the virus in attempts to control the looper experimentally.

The spectacular suddenness with which the disease appeared at Aylmer may perhaps be attributed to the unusually high temperatures, $9.8^{\circ} \mathrm{F}$. above normal, that prevailed during the first 10 days of September. During the 48-hour interval between visits to the field on September 8 and 10, the mean temperature recorded at the Central Experimental Farm, Ottawa, was $76.5^{\circ} \mathrm{F}$. That temperature governs the incubation period of the virus has been noted by other workers $(1,5)$.

\section{REFERENCES}

1. Hall, I. M. Use of a polyhedrosis virus to control the cabbage looper on lettuce in California. J. Econ. Entom. 50:551-553. 1957.

2. Harcourt, D. G. Occurrence of a DDT-resistant strain of the cabbage looper, Tricboplusia ni (Hbn.), in the Ottawa Valley. Can. J. Agr. Sci. 36:430-434. 1956.

3. Hayslip, N. C., W. G. Genung, E. C. KeIsheimer, and J. W. Wilson. Insects attacking cabbage and other crucifers in Florida. Florida Agr. Expt. Sta. Bull. 534. 1953.

4. McEwen, F. L., and G. E. R. Hervey. Control of the cabbage looper with a virus disease. J. Econ. Entomol. 51:626-631. 1958.

5. Semel, M. Polyhedrosis wilt of cabbage looper on Long Island. J. Econ. Entom. 49:420-421. 1956.

6. Steinhaus, E. A. Principles of insect pathology. McGraw-Hill Book Co., Inc., New York, N.Y. 1949.

March 2, 1960

-D. G. Harcourt,

Entomology Research Institute,

Research Branch,

Canada Department of Agriculture, Ottawa, Ontario 